\title{
English Prepositions of Time Translated into Albanian
}

\author{
Meliha Brestovci \\ University of Prishtina, Kosovo \\ Sadete Ternava-Osmani \\ University of Prishtina, Kosovo
}

\begin{abstract}
The study of language as a form of communication includes the structure and rules under which words interrelate. Scholars are facing the need for research on difficult issues and comparisons at the global and local level. The theme of this research is prepositions of time. Its aim is to deepen the knowledge of distinct prepositions and their use. Several comparative studies of this nature exist regarding the English and Albanian languages; it is tried to update the studies to facilitate students' acquisition of English as a foreign language and the work of translators between English and Albanian. On the basis of this research, the question rises as: How English prepositions of time for and after are translated into Albanian? In order to clarify the research, it was studied the use of prepositions, particularly prepositional phrases with emphasis on prepositions of time (for and after), and compared them with prepositions in the Albanian language from selected novels in English and Albanian. The research is based on a corpus of four novels, two by English authors and two by an Albanian writer. This research looked into analytical and comparative nature with the aim of enhancing and improving the current state of learning and it resulted that our assumption was right as these prepositions were translated as it was expected in the dictionary.
\end{abstract}

Index Terms - preposition, time, for, after, analysis, language

\section{INTRODUCTION}

Languages as a mean of communication are used in order people could be understood with each other and express their ideas, opinions, meanings, feelings etc. During history some languages survived the time and made themselves as superior or more used ones.

Mastering the use of prepositions in English, in both speaking and writing, is one of the most difficult tasks that students face. Prepositions pose problems not only to lower-level learners but also to the more advanced ones. Beginners who start learning English face the same problem, needing to search the best way to use English prepositions, which are sometimes not easy due to their multiple meanings. Learners may encounter several challenges in using them properly, but the main problems are as follows:

a) Which preposition should be used if required? And

b) What prepositions are "a must"?

This paper specifies the use and translation of certain prepositions in English such as preposition for and after, as from the analysis, preposition for appeared to be the third most used preposition after the preposition in and at.

This research, besides prepositions, also included prepositional phrases, considered among the main elements of noun phrases in English grammar. In Albanian grammar prepositions are often expressed through the noun cases.

\section{METHODOLOGY}

The study will be based on a corpus of four novels, two by English authors and two by an Albanian writer. The first two novels translated from English into Albanian include:

"White Fang" by Jack London, translated by Mikaela Minga as "Dhëmbi i Bardhë" (hereinafter as W. F. and Dh. B.); and "Dubliners" by James Joyce, translated into Albanian by Idlir Azizi as "Dublinasit" (hereinafter used as D. and Dubl.).

The two Albanian novels are by the well-known Albanian writer Ismail Kadare: "Darka e gabuar" translated by John Hodgson as "The fall of the stone city" (hereinafter used as D.G. and FSC); and "Kronikë në gur" translated into English by Arshi Pipa as "Chronicle in Stone" (hereinafter used as K.G. and C.S).

The decision to base the study on the above-mentioned novels derived from the fact that both Jack London and James Joyce stand in high regard in both languages, and as such have been translated into the targeted language.

The same stands for the Albanian corpus, as Ismail Kadare is one of the most translated Albanian writers, especially into French and English. Moreover, the two novels were translated directly from Albanian into English. There were other novels translated into English, but they were first translated from Albanian into French and then from French into English. 
In the above-stated novels, prepositions of time are treated according to their grammatical function, namely to semantic nuances brought from one language to another, from English into Albanian and vice versa. As semantics is the study of meaning communicated through language, we will be looking into the meaning of prepositions in sentences.

Also this research looked into the possibility of other variables of translation or non-translation within different situations in both languages, respectively in the four novels as well as a research was conducted with students of secondary school to see how they translate and how close to the dictionary are the translations. As we expected, the students identified and knew how to translate the test given to them.

With the development of linguistics, prepositions have been targeted by many linguists of the modern world. A deep insight was made into the structure, which in some respects clarified features that were not present before. All this came as a result of the prevailing opinion on prepositions, being of a very questionable nature and bearing a dichotomy as both lexical and functional.

According to Littlefield (2003) "statistically, in a corpus of one million English words, one in ten words is a preposition. Yet, despite their frequent occurrence, there is no generally accepted account of this category and its characteristics. At best, prepositions represent a problematic, contradictory category for theories of syntax." (pp.1-10)

\section{RESUlTS AND ANALYSIS}

Most simple prepositions in English are translated into Albanian with prepositions or with a single word, for example the prepositions in, on, at, for, after, etc. That word can be the preposition në (in, at, on), for (për) indicating time after (pas) adverbs of time (atëherë, pastaj), or by a noun phrase (for-disa çastesh, çastin).

Translated with prepositions:
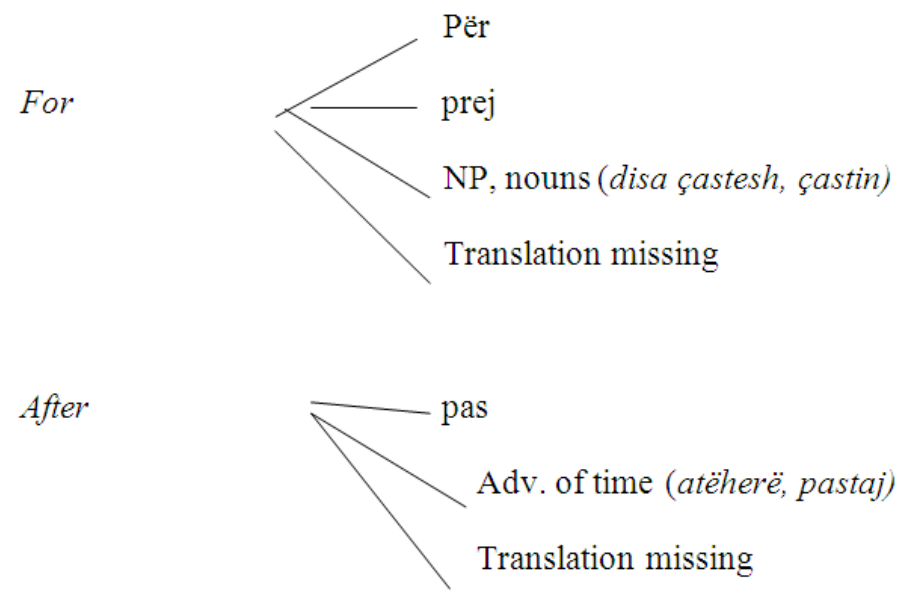

According to the analyzed novels, preposition for is the third most used preposition denoting time, after prepositions in and at, as it was found to be used in White Fang 476 times in total and 65 denoting time; in Dubliners 508 times and 71 denoting time.

\section{English For-Albanian Për}

1. Bill stopped for a moment, in order that his words might gain greater significance... (W. F. p. 6); (Billi heshti për një çast, si për t’u dhënë rëndësi më të madhe fjalëve që do të shqiptonte... (Dh. B. p. 8)).

2. ... where it had remained for weeks, a rankling flame ... (W. F. p. 42) (...më thellë se të tjerët dhe për javë të tëra i ishte dashur... (Dh. B. p. 47)).

3. I sat staring at the clock for some time, and when its tickling... (D. p. 25); (Pashë orën e murit për pak çaste dhe kur tik-taket e saj filluan... (Dubl., p. 50)).

4. There was a pause for a few seconds; and a great deal of scuffling...(D. p. 107); Heshtja kaloi për disa çaste, pastaj vrundull këmbëzvarrjesh...(Dubl., p. 135)

As seen from the above examples, prepositionfor was mainly tranlslated with preposition për in Albanian denoting a fixed time (for a moment, for a quarter of an hour, for five or ten muntes) but mostly showing duration of time (for a week, for a little time, for some time). Prepositional phrases with for may be simple containing $\mathrm{P}+\mathrm{N}$ (for weeks) or they may be complex $\mathrm{P}+\mathrm{NP}$ where the NP is preceded by modifiers (for some time, for a few seconds).

In Albanian they appear translated with $\mathrm{P}+\mathrm{NP}$ preceded by modifiers (adverb, indefinite pronoun) as well (për pak çaste, për disa çaste). Therefore, the same structure is in both languages $(\mathrm{P}+\mathrm{NP})$.

\section{English For - Albanian NP and Nouns}

1. For a week she never left the cave, except for water, and then her movements were slow and painful. (W. F. p. 65); (Pastaj qëndroi një javë në shpellë; dilte vetëm sa për të pirë ujë, duke lëvizur ngadalë... (Dh. B. p. 70)).

2. The moment Mit-Sah gave his order for the start, that moment the whole ... (W. F. p. 111); (Kur Mit-sahu jepte sinjalin e nisjes, ai lëshohej përpara.... (Dh. B. p. 115)). 
3. For days his manifestations of desire to lay hands on him had been... (W. F. p.123); (Kohët e fundit ai kishte qëndruar më shumë jashtë. (Dh. B. p. 127)).

4. ...too many battles to be in doubt for a moment what to do. (W. F. p. 35) (...shumë luftimeve dhe e dinte saktësisht çastin kur duhej tësulmonte.(Dh. B. p. 38)).

As in the above examples, PP's with HP for appear translated with NP into Albanian, and those NP's may have a modifier (një, disa) or may be just nouns (e nisjes, kohët e fundit). Nouns may have a front article $e$ which makes the noun in genitive (e nisjes) and (kohët) a feminine noun, plural in accusative, whereas the noun çastin is masculine, singular in accusative.

\section{English For-Albanian Prej}

1. ..., he had been employed for thirteen years in a great Catholic wine-merchant`s office... (D. p. 60) (.., ai punonte prej trembëdhjetë vjetësh në një zyrë të madhe tregtarësh katolikë të verës, ... (Dubl., p. 89)).

2. He had been for many years cashier of a private bank. (D. p. 104); (Prej shumë vitesh punonte si arkëtar i një banke private. (Dubl., p. 139)).

3. They had been married for twenty two years and had lived happily... (D. p. 111); (Kishin qenë të martuar prej njëzet e dy vjetësh dhe martesa e tyre .... (Dubl., p. 146)).

The examples above, when English preposition for is translated with the Albanian preposition prej, were found only in Dubliners (8 times). The PP in Albanian is composed of P $+\mathrm{NP}$ where a noun is preceded by a numeral (trembëdhjetë, njëzet e dy) and an adverb as modifier (shumë) and the nouns (vitesh, vjetësh) are in ablative case.

\section{English For -Translation Missing}

1. The circle of eyes to shift restlessly for a moment and even to withdraw a bit... (W. F. p. 7); (Edhe në rrethet e syve të përfaktë u pa hutim. (Dh. B. p. 10)).

2. For the time, fear had been routed by growth, while growth .... (W. F. p. 54); (Frikën e kishte mposhtur kureshtja. (Dh. B. p. 59)).

3. ....to break out of the eariness of school-life for one day at least. (D. p. 13) (...vendosa ta thyeja përditshmërinë e shkollës, të paktën një here. (Dubl., p. 36)).

4. when she had been laid up for a day.... (D. p. 32) (...kur ajo rastisi të zinte shtratin, ai i pati lexuar.... (Dubl., p.58)).

In White Fang more translations were found missing than in Dubliners (20-11). The underlined PP's were not translated or replaced by other words or phrases, although we think that they could have been translated with the preposition për (for a moment - për njëçast; for one day - për një ditë), adverb (tani), expression (for the time - tani për tani) or noun (for a day - ditën). Therefore, these cases show absence of translation and consequently the reader cannot have a clear picture of the time in the sentences. Let us see all these statistics in a tabular manner as follows:

TABLE 1.

WHITE FANG.

\begin{tabular}{|c|c|c|c|}
\hline \multicolumn{2}{|c|}{ Translation used for analysis } & Times & $\%$ \\
\hline \multicolumn{2}{|c|}{ English PP with the head for used - in total } & 476 & $100 \%$ \\
\hline \multicolumn{2}{|c|}{ for denoting time } & 66 & $100 \%$ \\
\hline \multirow{5}{*}{$\begin{array}{l}\text { PP with the head } \\
\text { for-translated into } \\
\text { Albanian }\end{array}$} & - with prepositions of accusative-për & 18 & $27.27 \%$ \\
\hline & -other prepositions: në, pas, me, rreth & 7 & $10.60 \%$ \\
\hline & $\begin{array}{l}\text {-with adverbs of time: (pak - 2; gjatë - } 6 \text {; tani - 1) } \\
\text {-verb phrases }-4\end{array}$ & $\begin{array}{l}9 \\
4 \\
\end{array}$ & $\begin{array}{l}13.63 \% \\
6.06 \% \\
\end{array}$ \\
\hline & $\begin{array}{l}\text {-cases when translation missing } \\
\text { - nouns }\end{array}$ & $\begin{array}{l}20 \\
3 \\
\end{array}$ & $\begin{array}{l}30.30 \% \\
4.54 \%\end{array}$ \\
\hline & - noun phrases & 5 & $7.57 \%$ \\
\hline
\end{tabular}

TABLE 2.

DUBLINERS

\begin{tabular}{|c|c|c|c|}
\hline \multicolumn{2}{|c|}{ Translation used for analysis } & Times & $\%$ \\
\hline \multicolumn{2}{|c|}{ English PP with the head for used - in total } & 508 & $100 \%$ \\
\hline \multicolumn{2}{|c|}{ for denoting time } & 71 & $100 \%$ \\
\hline \multirow{5}{*}{$\begin{array}{l}\text { PP with the head } \\
\text { for -translated into } \\
\text { Albanian }\end{array}$} & - with prepositions of accusative - për & 34 & $47.88 \%$ \\
\hline & -other prepositions: në, nga, rreth & 4 & $5.63 \%$ \\
\hline & $\begin{array}{l}\text {-with adverbs of time } \\
\text {-preposition: prej }\end{array}$ & $\begin{array}{l}3 \\
8\end{array}$ & $\begin{array}{l}4.22 \% \\
11.26 \%\end{array}$ \\
\hline & $\begin{array}{l}\text { - cases when translation missing } \\
\text { - conjuction (edhe) }\end{array}$ & $\begin{array}{ll}11 \\
3\end{array}$ & $\begin{array}{l}15.49 \% \\
4.22 \%\end{array}$ \\
\hline & - noun phrases and nouns & 8 & $11.26 \%$ \\
\hline
\end{tabular}

As seen from the tables, preposition për carries the burden of English translation for into Albanian. As for preposition për in Albanian, in both novels it appeared to be used in The Fall of the Stone City 382 times, and only 46 times denoting time, from 46 times only për - for (15); translation missing (13); prej - for (6); NP - for (një copëherë, një grime kohë, ca caste - 13); nouns - for (koha, ditë e netë - 2); VP - for (kaq shumë, kaq javë, kaq muaj), etc.

In Chronicle in Stone preposition për is used 426 times, 42 - denoting time; and other expressions translated into English prepositionfor such as: për - for (31); për - translation missing (9); prej - for (9); NP - for (një orë, orë të tëra, 
ca ditë - 27); VP - for (6); adverbs - for (pak, gjatë - 6), etc. All in all, approximately the same picture is gained as with preposition for in English.

\section{Analysis of Preposition After}

As stated above, preposition after, in regard to time relation, was used very often in the analysed novels in English; it was found in White Fang 104 times, 53 denoting time, and in Dubliners, out of 115, 88 denoting time.

\section{English After -Albanian Pas}

Preposition after is mostly translated with preposition pas into Albanian, showing a time after something, and in Dubliners out of 115 times it was found to be translated 51 times with pas into Albanian, whereas in White Fang out of 104 times, only 24 were translated with pas. This difference probably depends on the novel's content and the translator; Dubliners had a more correct translation than White Fang, whose translator several times produced sentences without translating them. Let us see some sentences in both novels:

1. After a time the she-wolf began to grow restless. (W. F. p. 35); (Pas disa sekondash ujkonja filloi të shfaqte një lloj shqetësimi. (Dh. B. p. 40)).

2. After a long while his monologue paused. (D. p. 18); (Pas një fare kohe monologu i tij rreshti. (Dubl., p. 42)).

3. had gone away quitly in couples after a few minutes...(D. p. 212) (...pas disa minutash u larguan qetë - qetë dy e nga dy. (Dubl., p. 233)).

As seen from the examples above, the preposition after is translated with preposition pas showing "a time after something". We found that preposition after was followed by a simple noun or NP (after dinner, after eight o `clock, after that evening) or by a more complex NP (after their first sleep). In Albanian as well, as stated in the previous paragraph on Albanian prepositions, PP's with the preposition pas are followed by a simple or complex NP and may have a modifier before a noun (pas darkës, pas një fare kohe, pas disa sekondash, etc.).

As observed during the analysis of the novels, both prepositions have a free placement in the sentence; they can be found in initial, middle or final positions within the sentence.

As happens with the preposition pas being found in the construction $\mathrm{N}+\mathrm{P}+\mathrm{N}$ (kohë pas kohe - now and then, herë pas here - from time to time, orë pas ore - hour by hour), we found the same construction with the preposition after as well: $\mathrm{N}+\mathrm{P}+\mathrm{N}$ (night after night-netëve me rradhë, morning after morning-çdo mëngjez, day after day-përnatë). Here the constructions are the same; translation differs as pas is translated more often with expressions and after appears translated with NP's preceded or not preceded by a modifier.

English After -Translation Missing

1. But after that he was afraid no more of the looming bulks of the tepees. (W. F. p. 74) (...Sidoqoftë nuk kishte më frikë prej tyre ... (Dh. B. p. 80)).

2. And after such classification he avoided the things that hurt..... (W. F. p. 52); (Ai thjeshtë i ndante gjërat në dy kategori: ato që të shkaktonin dhimbje... (Dh. B. p. 57)).

3. ...said Gallahar, emerging after some time from the clouds of smoke... (D. p. 73); (Tha Gallaheri duke dale prej reve të tymit ku ishte zhdukur. (Dubl., p. 104)).

4. The people are in bed and after their first sleep now... (D. p. 26); (Njerëzia kanë rënë për të fjetur tani, madje duhet ta kenë bërë gjumin e parë... (Dubl., p. 51)).

5. The next morning after breakfast I went down to look at the little house... (D. p. 3) (Të nesërmen në mëngjez vajta ta shihja në shtëpinë e vogël... (Dubl. p. 26)).

As seen from the examples above, PP with its head after may be simple (after that) or more complex (after their first sleep); nevertheless, the underlined PP's were not translated and they were not even replaced. Another fact to be mentioned, in comparison to other prepositions, is that there weren't many cases of non-translation especially in Dubliners, where the translator adapted somehow the translation as in the last two examples [although in the translation into Albanian it is not sure whether they ate breakfast or not, as it refers only to a part of the day (the next morning after breakfast - Të nesërmen në mëngjez)].

In White Fang there were 12 cases when PP was not translated or replaced. There were also cases when the whole sentence was missing in translation (And after two or three painful adventures with the mothers of part grown puppies...p.78). These are considered loss of translation.

Other translations found were: with adverbs of time such as: atëherë and pastaj (especially the PP after that - pastaj); pak, gjatë (and sleeping through after that evening - e të përgjumura gjatë gjithë mbrëmjes (D. p. 32:50)): with VP (it was after eight o`clock - kish kaluar teta...(D. p. 34; 51)); with $N P$, especially when there were expressions in English (night after night - netëve me rradhë; morning after morning - çdo mëngjez).

Apart from other discussed prepositions so far, the preposition after was found preceded by its complement and it

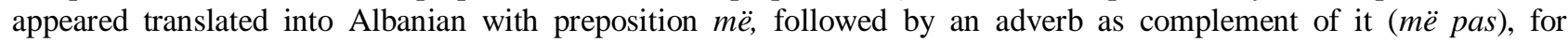
example:

1. Two nights after, his friends came to see him. (D. p. 155); (Dy netë më pas erdhën miqtë për vizitë. (Dubl., p. 198)).

2. ...out going a few days after. (D. p. 56) (..., ca ditë më pas. (Dubl., p. 85)).

During the analysis of the Albanian novels, approximately the same picture emerged from translation in English, so in Darka e Gabuar(The Fall of the Stone City) preposition pas - after (27), NP - after (2), më pas - after (1), nga -after (2), and in Kronikë në Gur (Chronicle in Stone)pas - after (15), Adv of time - after (2), NP - after (2). 
Let us see statistics about the preposition after and its translation into Albanian.

TABLE 3.

WHITE FANG.

\begin{tabular}{|l|l|l|l|}
\hline Translation used for analysis & Times & $\%$ \\
\hline English PP with the head after used - in total & $104-56$ & $100 \%$ \\
\hline after denoting time & 56 & $100 \%$ \\
\hline \multirow{2}{*}{$\begin{array}{l}\text { PP with the head } \\
\text { after -translated }\end{array}$} & - with preposition of ablative - pas & 24 & $42.85 \%$ \\
\cline { 2 - 4 } & - other prepositions: për, më, prej & 6 & $10.71 \%$ \\
& - që & 2 & $3.57 \%$ \\
\cline { 2 - 4 } & -verb phrase & 1 & $1.78 \%$ \\
\cline { 2 - 4 } & - cases when translation missing & 12 & $21.42 \%$ \\
& - adverbs of time (pastaj,atëherë) & 5 & $8.92 \%$ \\
\cline { 2 - 4 } & - expressions & 2 & $3.57 \%$ \\
& - conjunction (pasi) & 4 & $7.14 \%$ \\
\hline
\end{tabular}

TABLE 4.

DUBLINERS

\begin{tabular}{|c|c|c|c|}
\hline \multicolumn{2}{|c|}{ Translation used for analysis } & times & $\%$ \\
\hline \multicolumn{2}{|c|}{ English PP with the head after used - in total } & $105-88$ & $100 \%$ \\
\hline \multicolumn{2}{|c|}{ after denoting time } & 88 & $100 \%$ \\
\hline \multirow{5}{*}{$\begin{array}{l}\text { PP with the head } \\
\text { after-translated } \\
\text { into Albanian }\end{array}$} & - with preposition of ablative - pas & 51 & $57.95 \%$ \\
\hline & -other prepositions: më, & 3 & $3.40 \%$ \\
\hline & $\begin{array}{l}\text { - verb phrase } \\
\text { - noun phrase }\end{array}$ & $\begin{array}{l}3 \\
3\end{array}$ & $\begin{array}{l}3.40 \% \\
3.40 \%\end{array}$ \\
\hline & $\begin{array}{l}\text { - cases when translation missing } \\
\text { - adverbs of time (pastaj, gjatë, pak) }\end{array}$ & $\begin{array}{l}16 \\
6\end{array}$ & $\begin{array}{l}18.18 \% \\
6.81 \%\end{array}$ \\
\hline & -conjunction (pasi) & 6 & $6.81 \%$ \\
\hline
\end{tabular}

\section{DISCUSSIONS AND CONCLUSIONS}

In the Introduction part of our research it is stated that a test is conducted on prepositions of time Since this research is based on the comparison between two languages, English and Albanian, we expected that translation (without dictionaries) would be satisfactory, believing that students would identify and translate them properly. This assumption was based on research done in the secondary school by a particular test which included prepositions of time (in, on, at, for, from, after, before). The test contained 14 sentences, each preposition appearing in two sentences for translation.

The reason why it was chosen the high school is that such schools are supposed to be the best in Kosova, and one of them is the High School "Zenel Hajdini" in Gjilan, profile "Natural Sciences", as they have the best students. As the Municipal Directorate for Education in Gjilan stated, the students of this profile showed great success in English in the last year graduation test (68\%). The test was appropriate only for the Intermediate level, which fits the students' experience of study; they started learning English as a second language at the age of 10 and so most of them were 17 at the time the test was given. Students translated without a dictionary; based on the above criteria, we believed and expected them to translate correctly.

The analysis of the test is shown on tables with the total number of respective prepositions, which were used 400 times each (in, on, at, for, from, after, before). All the prepositions were used twice, showing time relations in the sentences given in the test. Since the test was done with 200 students, there were a total of 400 prepositions per each preposition. The following tables illustrate in detail the translation of the above-mentioned prepositions and in this research prepositions for and after.

Table 5. Preposition FOR

\begin{tabular}{|l|l|l|}
\hline FOR & 400 & \multicolumn{1}{|c|}{$\%$} \\
\hline for-për & 395 & $98.75 \%$ \\
\hline for-tr.miss & 5 & $1.25 \%$ \\
\hline
\end{tabular}

Table 6. Preposition AFTER

\begin{tabular}{|l|l|l|}
\hline AFTER & 400 & \multicolumn{1}{|c|}{$\%$} \\
\hline after - pas & 392 & $98 \%$ \\
\hline after - tr.miss & 4 & $1 \%$ \\
\hline after - para & 2 & $0.5 \%$ \\
\hline after - nga & 1 & $0.25 \%$ \\
\hline after - rreth & 1 & $0.25 \%$ \\
\hline
\end{tabular}

According to the analyzed novels, the preposition for is the third most used preposition denoting time, after the prepositions in and at. Preposition FOR was the easiest preposition for the students to translate; they consistently translated it with the Albanian preposition për $(98.75 \%)$. If we go back and see the Albanian preposition për translated into English, there is about the same situation: për - for in C. S. (73.80\%) and less in FSC (31.25\%) as it depends on the content of the story and the translator. 
The preposition AFTER showed no problem to students as it was found to be translated into the Albanian preposition pas (98\%). Out of that percentage, it was translated only 5 times with mbas, which is an old form of the preposition pas.

In conclusion to this research, it is observed that students translated correctly all the above-mentioned prepositions. Therefore, according to their translations without dictionaries, it is believed that students better recognize prepositions of time than of place, and that they make more mistakes in translating prepositions of place than those of time. Prepositions of place may pose problems; they have idiomatic meanings while prepositions of time seem quite clear.

\section{REFERENCES}

[1] Aarts, B. (2001). English Syntax and Argumentation (Second Edition). London: Palgrave Macmillan.

[2] Adams, E. Aerts, J. (1988). English Syntactic Structures. New York, Toronto, Sydney, Tokyo, Singapore: Prentice Hall and Martinus; Leyden, Antwerp: Martinus Nijhoff.

[3] Adams, V. (1973). An Introduction to English Word-Formation. London: Longman.

[4] Biber, D., Conrad, S. Leech, G. (2008). Student Grammar of Spoken and Written English. Longman Person Education Limited, Edinburgh Gate-Harlow, Essex CM20 2JE, England.

[5] Blackmore, D. (2002). Relevance and Linguistic Meaning, The Semantics and Pragmatics of Discourse Markers. Cambridge: Cambridge University Press.

[6] Crystal, D. (1997). The Cambridge Encyclopedia of the English Language. Cambridge. Cambridge University Press.

[7] Demiraj, Sh., (1988). Gramatika Historike e Gjuhës Shqipe. Parafjalët (Historical Grammar of the Albanian Language. Prepositions. Prishtina. pp.31-650.

[8] Essberger, J. (2012). English Prepositions List, EnglishClub.com, 23 King Street, Cambridge CB1 1AH, England, UK.

[9] Fjalor i Gjuhës Shqipe (Albanian Dictionary- Albanian Academy of Sciences) (2006). Tirana, Albania, ISBN 99943-817-5-X.

[10] Huddleston, R., Pullum, G. K. (2002). The Cambridge Grammar of the English Language. Cambridge University Press, Trumpington Street, Cambridge, United Kingdom.

[11] Lindstromberg, S. (1998). English Prepositions Explained. John Benjamin`s Publishing Co. Amsterdam.

[12] Littlefield, H. (2003). Lexical and Functional Prepositions in Acquisition: Evidence for a Hybrid Category, Heather Littlefield Boston University, p.1-10.

[13] Mardale, A. (2011). Prepositions as a Semilexical Category. Bucharest Working papers in Linguistics, 13. (2), p. 35-50.

[14] Xhuvani, A. (1964). Parafjalët (Prepositions). Studime Filologjike 1. (Philological Studies 1), Institute of Linguistics, Tirane, Albania.

Meliha Brestovci was born in Gjilan, Kosovo in 1972. She received her PH.D. degree in linguistics from SEEU Tetovo in Macedonia in 2015.

She is currently a lector in the Pubic University of Prishtina, Kosovo. Her interests incude psycholinguistics as well. She also is a free interpreter and translates different documents in her free time.

Mrs. Brestovci took part in several seminars and conferences where she presented her work such as in Kosovo, Albania, Turkey and they were mostly in the field of linguistics.

Sadete Tërnava-Osmani was born in Prishtina, Kosovo in1968. She received her master's degree in applied linguistics from Faculty of Philology, University of Prishtina, Kosovo in 2007.

She is currently a lector in the Public University of Prishtina, Kosovo. She is also in charge of editing the in-house journals and papers. Her research interest includes methodology of language teaching, translation and sociolinguistics.

Mr.sc Tërnava has published a book with poems and is an author to several publications in the field of pedagogy of teaching. She is a member of the writers' association "BeqirMusliu", Gjilan, Kosovo. 